\title{
PENGARUH SOSIALISASI PERPAJAKAN DAN SANKSI PERPAJAKAN TERHADAP KEPATUHAN PELAPORAN SPT TAHUNAN WAJIB PAJAK ORANG PRIBADI
}

\author{
Tri Nurdyastuti ${ }^{1)}$ \\ Adi Penawan 2) \\ STIE Adi Unggul Bhirawa Surakarta \\ E-mail : tri.nurdyastuti@stie-aub.ac.id
}

\begin{abstract}
The puspose of this study to know effect of taxation socialization and tax sanctions on compliance reporting annual taxpayer personal taxpayer.

Population in this research is all personal taxpayer registered at KPP Pratama Surakarta amounted 104,192 taxpayer. The sample was taken by using simple random sampling method as much as 100 respondents. The technique of analysis in this study using classical assumption test techniques and using multiple linear regression analysis test.

The results of this study indicate that the socialization of taxation and taxation sanctions simultaneously affect taxpayer compliance. Partially taxation and taxation sanctions partially affect the taxpayer compliance of individuals registered at KPP Pratama Surakarta.
\end{abstract}

Keywords: Socialization of taxation, Tax Sanctions, Taxpayer Compliance

\begin{abstract}
Abstrak
Penelitian ini bertujuan untuk mengetahui pengaruh sosialisasi perpajakan dan sanksi perpajakan terhadap kepatuhan pelaporan SPT tahunan wajib pajak orang pribadi.

Populasi dalam penelitian ini adalah seluruh wajib pajak orang pribadi yang terdaftar pada KPP Pratama Surakarta berjumlah 104.192 wajib pajak. Sampel diambil dengan menggunakan metode simple random sampling sebanyak 100 responden. Teknik analisis dalam penelitian ini menggunakan teknik uji asumsi klasik serta menggunakan uji analisis regresi linear berganda.

Hasil penelitian ini menunjukkan bahwa sosialisasi perpajakan dan sanksi perpajakan secara simultan berpengaruh terhadap kepatuhan wajib pajak. Secara parsial sosialisasi perpajakan dan sanksi perpajakan berpengaruh terhadap kepatuhan wajib pajak orang pribadi yang terdaftar pada KPP Pratama Surakarta.
\end{abstract}

Kata kunci : Sosialisasi Perpajakan, Sanksi Perpajakan, Kepatuhan Wajib Pajak

\section{A. Pendahuluan}

Pajak merupakan salah satu sumber penerimaan utama negara yang digunakan untuk membiayai pengeluaran pemerintah dan pembangunan. Pajak merupakan wujud dari peran serta masyarakat dalam mendukung pembangunan maupun perekonomian di Indonesia. Pajak dipungut berdasarkan ketentuan UU Perpajakan tanpa jasa timbal balik secara langsung dari Negara (R. Viktor Billi Josua Tawas, Agus T. Poputra, 2016)

Pendapatan dari sektor pajak setiap tahun selalu diupayakan mengalami kenaikan. Dalam rangka mendukung pencapaian target penerimaan negara dari sektor pajak, pemerintah telah melakukan berbagai upaya dalam bidang perpajakan yaitu dengan reformasi perpajakan (tax reform) yang mencangkup usaha dan penyempurnaan sistem serta mekanisme perpajakan dari yang sebelumnya yang telah ada. Salah satu contoh perubahan yang terjadi di dalamnya adalah perubahan dari Official Assessment System menjadi Self Assessment System. Beralihnya sistem perpajakan dari official assessment system menjadi self assessment system bukan karena salah satu diantara kedua sistem tersebut lebih baik, melainkan adanya upaya dari pemerintah untuk menyesuaikan sistem perpajakan sesuai dengan tuntutan perubahan sistem perekonomian dan perkembangan dalam masyarakat (Mardiasmo, 2016).

Perubahan tersebut memberikan kepercayaan sekaligus tuntutan peran serta masyarakat sebagai wajib pajak untuk secara aktif melakukan kewajiban perpajakannya. Dimana penentuan besarnya pajak yang terutang dipercayakan kepada wajib pajak sendiri untuk melaporkan secara teratur jumlah pajak yang terutang dan 
membayar yang terutang sesuai dengan ketentuan yang ditentukan dalam peraturan perundang-undangan perpajakan. Dengan diberikannya kepercayaan penuh kepada wajib pajak selayaknya diimbangi dengan pengawasan, supaya kepercayaan yang diberikan tidak disalah gunakan. Ini menjadikan tugas Direktorat Jenderal Pajak untuk menetapkan pajak setiap wajib pajak menjadi berkurang. Tugas pokok Direktorat Jenderal Pajak dalam hal ini khususnya sangat menonjol sesuai dengan fungsinya adalah melakukan pembinaan, penelitian, pengawasan, dan pelayanan dalam hubungan dengan pelaksanaan kewajiban perpajakan dari wajib pajak sesuai dengan ketentuan yang diatur dalam Peraturan Perundang-undangan Perpajakan yang berlaku.

Persoalan yang sejak dulu tidak terlepas dari masalah perpajakan ialah kepatuhan wajib pajak. Kepatuhan wajib pajak untuk memenuhi kewajiban perpajakannya perlu di tingkatkan demi terciptanya target pajak yang diinginkan (Doran, 2009). Kepatuhan yang meningkat akan mendukung upaya pemerintah untuk meningkatkan kesejahteraan masyarakat (Gerald, 2009). Ocheni (2015) menyatakan kepatuhan wajib pajak dengan kesediaan membayar pajak sangat penting dan tidak dapat diabaikan. Chau (2009) berpendapat bahwa faktor yang mempengaruhi penerimaan pajak suatu daerah diantaranya adalah tingkat kepatuhan wajib pajak masyarakat di daerah tersebut. Torgler (2005) mengatakan bahwa, salah satu masalah yang paling serius bagi para pembuat kebijakan ekonomi adalah mendorong tingkat kepatuhan wajib pajak. Motivator utama dari kepatuhan wajib pajak adalah sanksi/denda yang ditetapkan oleh otoritas pajak (Witte dan Woodbury, 1985). Kepatuhan wajib pajak merupakan faktor penting bagi peningkatan pajak, maka perlu secara insentif dikaji tentang faktor-faktor yang mempengaruhi kepatuhan wajib pajak, khususnya dalam membayar pajak daerah (Nazmel, 2010).

Presentase rasio kepatuhan wajib pajak dalam melaksanakan pemenuhan kewajiban perpajakannnya dari tahun ke tahun masih belum menunjukkan peningkatan secara berarti. Hal ini didasarkan pada perbandingan jumlah wajib pajak yang memenuhi syarat patuh di Indonesia yang jumlahnya sedikit sekali jika dibandingkan dengan jumlah total wajib pajak terdaftar. Dari sekian banyak wajib pajak yang ada, sebagian besar wajib pajak belum mengerti apa saja yang menjadi hak dan kewajibannya. Oleh karena itu, Direktorat Jenderal Pajak yang diwakili oleh Kantor Pelayanan Pajak Pratama Surakarta berupaya meningkatkan pengetahuan dan pemahaman wajib pajak akan dunia perpajakan. Dalam mengurus pajaknya sendiri wajib pajak dituntut aktif. Upaya yang dilakukan Kantor Pelayanan Pajak Pratama Surakarta untuk meningkatkan pengetahuan dan pemahaman wajib pajak akan hak dan kewajibannya salah satunya adalah dengan sosialisasi perpajakan. Melalui sosialisasi diharapkan Wajib Pajak patuh akan kewajibannya dan mendapatkan haknya. Dalam upaya memenuhi hak pelayanan wajib pajak, Kantor Pelayanan Pajak Pratama Surakarta menciptakan akuntabilitas yang berarti menyelaraskan prosedur pelayanan sesuai dengan aturan yang ada demi kepuasan wajib pajak. Hal lain yang tak kalah penting adalah penegakan hukum yang ketat oleh aparat perpajakan berupa sanksi perpajakan jika wajib pajak terlambat atau tidak memenuhi kewajibannya. Pada hakikatnya, pengenaan sanksi perpajakan diberlakukan untuk menciptakan kepatuhan wajib pajak dalam melaksanakan kewajiban perpajakannya. Itulah sebabnya, penting bagi wajib pajak memahami sanksi-sanksi perpajakan sehingga mengetahui konsekuensi hukum dari apa yang dilakukan ataupun tidak dilakukan (Winerungan, 2013).

Konstribusi dalam penelitian ini adalah diharapkan dapat meningkatkan kepatuhan wajib pajak di Surakarta dengan mengoptimalkan sosialisasi perpajakan dan sanksi perpajakan sehingga akan meningkatkan sumber penerimaan utama negara yang digunakan untuk membiayai pengeluaran pemerintah dan pembangunan.

\section{B. Telaah Literatur dan Pengembangan Hipotesis}

\section{Teori Dasar Pajak}

a. Pengertian pajak

Menurut Mardiasmo (2016:3) pengertian pajak adalah kontribusi wajib kepada negara yang terutang oleh orang pribadi atau badan yang bersifat memaksa berdasarkan Undang-Undang, dengan tidak mendapatkan imbalan secara langsung dan digunakan untuk keperluan negara sebesar-besarnya kemakmuran rakyat.

b. Fungsi Pajak

Ada dua fungsi pajak menurut Mardiasmo (2016:4), yaitu: (1) Fungsi budgetair yaitu Pajak sebagai sumber dana bagi pemerintah untuk membiayai pengeluaran-pengeluarannya, (2) Fungi mengatur (regulerend) yaitu Pajak sebagai alat untuk mengatur atau melaksanakan kebijaksanaan pemerintah dalam bidang sosial dan ekonomi.

\section{c. Dasar Hukum Pengenaan Pajak Penghasilan}

Dasar hukum pengenaan Pajak Penghasilan (PPh) adalah Undang-Undang Nomor 7 Tahun 1984 sebagaimana telah diubah terakhir dengan Undang-Undang Nomor 36 Tahun 2008. Undang-Undang Pajak Penghasilan berlaku mulai tahun 1984 dan merupakan pengganti UU Pajak Perseroan 1925, UU Pajak Pendapatan 1944, UU PBDR 1970. 


\section{Surat Pemberitahuan (SPT)}

Menurut Mardiasmo (2016:35) Surat Pemberitahuan (SPT) adalah surat yang oleh wajib pajak digunakan untuk melaporkan perhitungan dan/atau pembayaran pajak, objek pajak dan/atau bukan objek pajak, dan/atau harta dan kewajiban sesuai dengan ketentuan peraturan perundang-undangan perpajakan.

\section{Pajak Penghasilan (PPh) Pasal 21}

Pajak Penghasilan (PPh) Pasal 21 adalah pajak yang dikenakan atas penghasilan wajib pajak orang pribadi dalam negeri yang berupa gaji, upah honorarium, tunjangan, dan pembayaran lain dengan nama apapun sehubungan dengan pekerjaan atau jabatan, jasa, dan kegiatan yang dilakukan oleh orang pribadi subjek pajak dalam negeri, sebagaimana dimaksud dalam pasal 21 UU Pajak Penghasilan. (Mardiasmo, 2016:197)

\section{Kepatuhan Pajak}

Pengertian Kepatuhan Wajib Pajak menurut Norman D. Nowak dalam Mohammad Zain (2007:31) adalah suatu iklim kepatuhan dan kesadaran pemenuhan kewajiban perpajakan, tercermin dalam situasi di mana: a). Wajib pajak paham atau berusaha untuk memahami semua ketentuan peraturan perundangundangan perpajakan, b). Mengisi formulir pajak dengan lengkap dan jelas, c). Menghitung jumlah pajak yang terutang dengan benar, d). Membayar pajak yang terutang tepat pada waktunya.

\section{Sosialisasi Perpajakan}

Sosialisasi perpajakan adalah upaya yang dilakukan oleh Dirjen Pajak untuk memberikan sebuah pengetahuan kepada masyarakat dan khususnya wajib pajak agar mengetahui tentang segala hal mengenai perpajakan baik peraturan maupun tata cara perpajakan melalui metode-metode yang tepat (Guntur Jati Wijayanto, 2017).

\section{Sanksi Perpajakan}

Menurut Mardiasmo (2016), sanksi perpajakan merupakan jaminan bahwa ketentuan peraturan perundang-undangan perpajakan (norma perpajakan) akan dituruti/ditaati/dipatuhi. Atau bisa dengan kata lain sanksi perpajakan merupakan alat pencegah (preventif) agar Wajib Pajak tidak melanggar norma perpajakan. Dalam undang-undang perpajakan dikenal dua macam sanksi, yaitu sanksi Administrasi dan sanksi pidana.

\section{Hasil Penelitian Terdahulu}

Penelitian yang dilakukan Gedhe Pani Esa Dharma \& Ketut Alit Suardana (2014) yang berjudul Pengaruh kesadaran wajib pajak, sosialisasi perpajakan, kualitas pelayanan pada kepatuhan wajib pajak menunjukkan hasil kesadaran wajib pajak, sosialisasi perpajakan, dan kualitas pelayanan secara parsial berpengaruh signifikan terhadap kepatuhan wajib pajak dalam membayar Pajak PKB dan BBNKB.

I Made Wahyu Cahyadi dan I Ketut Jati (2016) berjudul Pengaruh kesadaran, sosialisasi, akuntabilitas pelayanan publik dan sanksi perpajakan pada kepatuhan wajib pajak kendaraan bermotor menunjukkan hasil Kesadaran wajib pajak, sosialisasi perpajakan, akuntabilitas pelayanan publik dan sanksi perpajakan berpengaruh signifikan terhadap kepatuhan wajib pajak kendaraan bermotor.

Ida Ayu Dewi Widnyani dan Ketut Alit Suardana (2016) berjudul Pengaruh sosialisasi, sanksi dan persepsi akuntabilitas terhadap kepatuhan wajib pajak dalam membayar pajak kendaraan bermotor menunjukkan hasil Sosialisasi perpajakan, sanksi perpajakan, dan persepsi tentang akuntabilitas pelayanan publik berpengaruh positif dan signifikan pada kepatuhan wajib pajak dalam membayar pajak kendaraan bermotor.

\section{Kerangka Pemikiran}

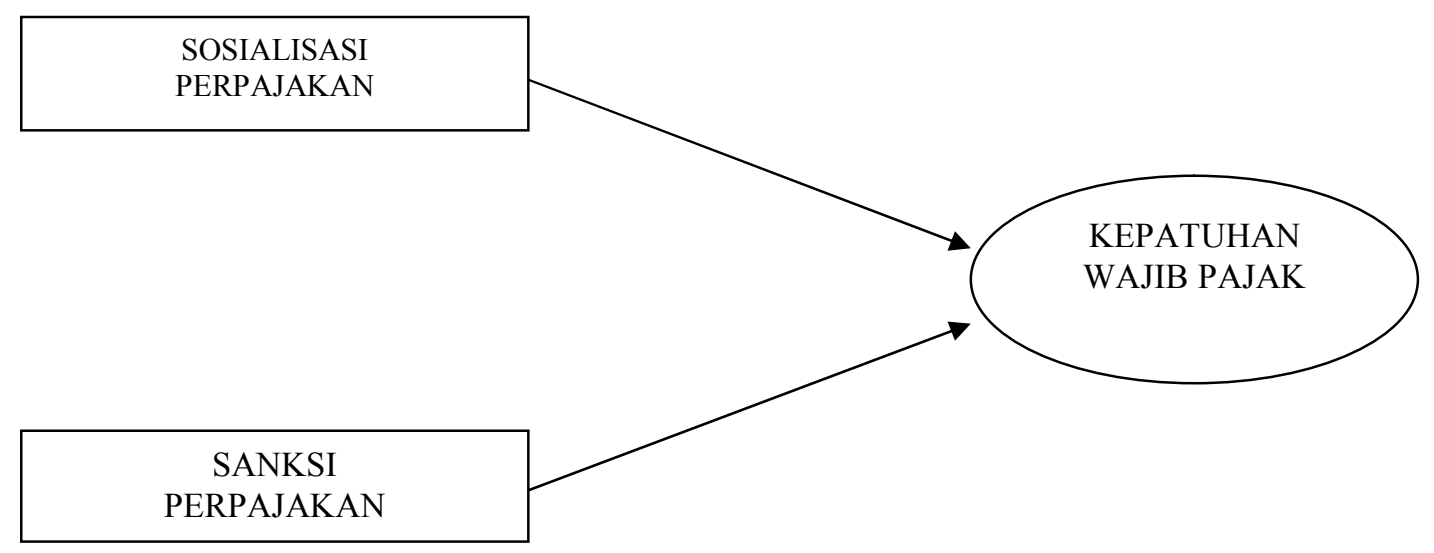




\section{Gambar 1. Kerangka Pemikiran \\ Sumber: Susilawati (2013), R Viktor, dkk (2016), Dharma, dkk (2014), I Ketut Jati dan I Made Wahyu}

(2016), Ida dan Suardana (2016)

\section{Hipotesis}

$\mathrm{H}_{1}$ : Pengaruh sosialisasi perpajakan terhadap kepatuhan wajib pajak orang pribadi dalam melaporkan SPT tahunan.

$\mathrm{H}_{2}$ : Pengaruh sanksi perpajakan terhadap kepatuhan wajib pajak orang pribadi dalam melaporkan SPT tahunan.

\section{Metode Penelitian}

Jenis penelitian ini adalah penelitian survey yang dilakukan pada wajib pajak orang pribadi yang terdaftar pada KPP Pratama Surakarta yang jumlahnya 104.192 wajib pajak, karena jumlah populasi yang besar maka jumlah sampel didasarkan pada pendapat Fraenkel dan Wallen dalam Widayat (2004:105) menyatakan bahwa jumlah sampel minimal adalah sebanyak 100 orang maka sampel yang digunakan dalam penelitian ini berjumlah 100 orang dengan teknik pengambilan sampel secara acak sederhana (Simple Random Sampling) yaitu teknik pengambilan sampel dimana semua anggota populasi diberikan kesempatan yang sama untuk dipilih sebagai anggota sampel (Sugiyono, 2010).

Jenis data dalam penelitian ini adalah data primer yaitu data yang diperoleh langsung dari wajib pajak orang pribadi yang terdaftar pada KPP Pratama Surakarta yaitu tentang persepsi mereka terhadap variabel Sosialisasi Perpajakan, Sanksi Perpajakan dan Kepatuhan Wajib Pajak. Metode pengumpulan data dalam penelitian ini berupa kuesioner.

Variabel dan definisi operasional dalam penelitian ini adalah:

1. Kepatuhan Wajib Pajak merupakan pemenuhan kewajiban perpajakan yang dilakukan oleh pembayar pajak dalam rangka memberikan kontribusi bagi pembangunan negara. Indikator: pendaftaran wajib pajak, penghitungan dan pembayaran pajak, pembukuan dan pelaporan SPT.

2. Sosialisasi perpajakan adalah upaya yang dilakukan oleh Dirjen Pajak untuk memberikan sebuah pengetahuan kepada masyarakat dan khususnya wajib pajak agar mengetahui tentang segala hal mengenai perpajakan baik peraturan maupun tata cara perpajakan melalui metode-metode yang tepat menurut Susanto dalam (Sugeng Wahono, 2012: 80). Indikatornya adalah: waktu dan penyelenggaraan sosialisasi, cara dan media sosialisasi, kebermanfaatan sosialisasi.

3. Sanksi Perpajakan menurut Jatmiko (2006), jika kewajiban pajak tidak dipatuhi, maka akan ada konsekuensi hukum yang terjadi kepada wajib pajak. Konsekuensi hukum adalah penerapan sanksi perpajakan. Penerapan tersebut berguna untuk memberikan efek jera kepada wajib pajak yang melanggar norma perpajakan sehingga tercipta kepatuhan wajib pajak dalam memenuhi kewajiban perpajakannya. Indikatornya adalah: sanksi pajak sangat diperlukan, sanksi dilaksanakan dengan tegas, sanksi sesuai dengan besar kecilnya pelanggaran, sanksi sesuai dengan ketentuan dan peraturan yang berlaku

Teknik analisis yang digunakan dalam penelitian ini adalah uji instrumen penelitian berupa uji validitas dengan metode one shot methode dan uji reliabilitas diukur dengan menggunakan teknik Cronbach's Alpha. Sebelum dilakukan analisis regresi linier berganda, maka model regresi linier tersebut harus lolos uji asumsi klasik, sebagai syarat berlakunya analisis regresi. Uji asumsi klasik terdiri dari uji multikolonieritas, uji autokorelasi, uji heteroskedasitas, dan uji normalitas (Ghozali, 2001:89-115) dan pengujian hipotesis dengan Uji Regresi Linier Berganda, uji t, uji F dan uji koefisien determinasi.

Model persamaan regresi analisis jalur dalam penelitian ini adalah:

$\mathrm{Y}=\beta_{1} \mathrm{X}_{1}+\beta_{2} \mathrm{X}_{2}+\varepsilon$

$\beta_{1}, \beta_{2} \quad$ Koefisien variabel $X_{1} \ldots X_{2}$

$\mathrm{Y}=$ Kepatuhan Wajib Pajak

$\mathrm{X}_{1} \quad=$ Sosialisasi Perpajakan

$\mathrm{X}_{2} \quad=$ Sanksi Perpajakan

$\varepsilon=$ Standar error

\section{Hasil dan Pembahasan}

\section{Hasil}




\section{a. Pengujian Instrumen Penelitian}

Hasil uji instrumen penelitian dapat dilihat dalam tabel di bawah ini:

Tabel 1. Pengujian Instrumen Penelitian

\begin{tabular}{ccclc}
\hline Pengujian & \multicolumn{1}{c}{ Uji } & \multicolumn{1}{c}{ Alat } & \multicolumn{1}{c}{ Variabel } & Status \\
\hline & \multirow{3}{*}{ Validitas } & & Sosialisasi Perpajakan & Valid \\
Instrumen & & One shot methods & Sanksi Perpajakan & Valid \\
Penelitian & \multirow{2}{*}{ Reliabilitas } & & Kepatuhan Wajib Pajak & Valid \\
& & \multirow{2}{*}{ Cronbach Alpha } & Sosialisasi Perpajakan & Reliabel \\
& & & Sanksi Perpajakan & Reliabel \\
& & & Kepatuhan Wajib Pajak & Reliabel \\
\hline
\end{tabular}

Sumber: Hasil olah data, 2017

Berdasarkan tabel di atas diketahui hasil uji instrumen variabel menunjukkan semua variabel valid dan reliabel.

\section{b. Uji Asumsi Klasik}

Hasil uji asumsi klasik dapat dilihat dalam tabel di bawah ini:

Tabel 2. Uji Asumsi Klasik

\begin{tabular}{|c|c|c|c|c|}
\hline Pengujian & $\mathbf{U j i}$ & Alat & Hasil & Status \\
\hline \multirow{4}{*}{$\begin{array}{l}\text { Uji Asumsi } \\
\text { Klasik }\end{array}$} & Multikolonieritas & Collinearity Statistics & $\begin{array}{c}\text { nilai VIF masing- } \\
\text { masing variabel } \\
\text { sebesar } 1,179<10 \text { dan } \\
\text { nilai Tolerance } \\
\text { masing-masing } \\
\text { variabel } 0,848>0,10\end{array}$ & $\begin{array}{c}\text { Tidak terjadi } \\
\text { multikolinieritas }\end{array}$ \\
\hline & Autokorelasi & durbin-watson & $\begin{array}{c}\text { Nilai D-W sebesar } \\
\text { 1,874. Nilai D-W } \\
\text { berada diantara -2 } \\
\text { sampai } 2\end{array}$ & $\begin{array}{c}\text { Tidak ada } \\
\text { autokorelasi }\end{array}$ \\
\hline & Heteroskedasitas & Glejser & $\begin{array}{c}\text { Nilai signifikansi } \\
\text { masing-masing } \\
\text { variabel sebesar } 0,537 \\
\text { dan } 0,209>0,05\end{array}$ & $\begin{array}{c}\text { Tidak terjadi } \\
\text { heteroskedastisitas } \\
\text { antar residual }\end{array}$ \\
\hline & Normalitas & Kolmogrov-Sminorv & $\begin{array}{c}\text { Nilai asymp } \\
\text { signifikansi K-S } \\
\text { sebesar } 0,371>0,05\end{array}$ & $\begin{array}{c}\text { Data terdistribusi } \\
\text { normal }\end{array}$ \\
\hline
\end{tabular}

Sumber: Hasil olah data, 2017

Sedangkan untuk uji asumsi klasik menunjukkan bahwa model dalam penelitian bebas dari asumsi klasik.

\section{c. Uji Regresi Linier Berganda}

Tabel 3. Hasil Uji Regresi Linier Berganda

\begin{tabular}{lcccc}
\hline \multicolumn{1}{c}{ Variabel } & Koefisien & t & Sig & Keterangan \\
\hline $\begin{array}{l}\text { Sosialisasi Perpajakan } \rightarrow \text { Kepatuhan } \\
\text { Wajib Pajak }\end{array}$ & 0,120 & 2,035 & 0,045 & Signifikan \\
$\begin{array}{l}\text { Sanksi Perpajakan } \rightarrow \text { Kepatuhan } \\
\text { Wajib Pajak }\end{array}$ & 0,143 & 2,071 & 0,041 & Signifikan \\
$\quad$ Sumber: Hasil olah data, 2017 & & & & \\
\hline
\end{tabular}

Sumber: Hasil olah data, 2017

Dari tabel di atas dapat dilihat hasil persamaan menunjukkan bahwa sosialisasi perpajakan dan sanksi perpajakan berpengaruh signifikan dengan nilai signifikan masing-masing variabel $<\alpha=0,05$.

\section{Pembahasan}

a. Pengaruh sosialisasi perpajakan terhadap tingkat kepatuhan wajib pajak orang pribadi pada KPP Pratama Surakarta. 
Hasil pengujian menunjukkan bahwa variabel sosialisasi perpajakan berpengaruh positif dan signifikan terhadap tingkat kepatuhan wajib pajak orang pribadi pada KPP Pratama Surakarta. Hasil ini menunjukkan bahwa peningkatan sosialisasi perpajakan mempunyai pengaruh positif, artinya jika sosialisasi perpajakan meningkat maka kepatuhan wajib pajak orang Pribadi pada KPP Pratama Surakarta cenderung meningkat. Sosialisasi Perpajakan yang diselenggarakan oleh Dirjen Pajak harus secara terus-menerus dilakukan untuk memperluas informasi serta memperdalam pengetahuan wajib pajak tentang perpajakan. Hasil penelitian ini sejalan dengan penelitian Viktor, Agus, dan Robert (2016) yang menyatakan bahwa sosialisasi perpajakan berpengaruh positif dan signifikan terhadap kepatuhan wajib pajak.

b. Pengaruh sanksi perpajakan terhadap tingkat kepatuhan wajib pajak orang pribadi pada KPP Pratama Surakarta.

Hasil pengujian menunjukkan bahwa variabel sanksi perpajakan berpengaruh positif dan signifikan terhadap tingkat kepatuhan wajib pajak orang pribadi pada KPP Pratama Surakarta. Hasil ini menunjukkan bahwa peningkatan sanksi perpajakan berpengaruh positif, artinya jika sanksi perpajakan yang penerapannya dilakukan secara tegas kepada wajib pajak akan mengakibatkan wajib pajak jera untuk lalai dalam melakukan kewajiban perpajakannya. Kepatuhan wajib pajak meningkat disebabkan wajib pajak yang telah memahami mengenai hukum perpajakan akan memilih untuk patuh dibandingkan dikenakan sanksi perpajakan yang lebih banyak merugikannya. Hasil penelitian ini sejalan dengan penelitian Viktor, Agus, dan Robert (2016) yang menyatakan bahwa sanksi perpajakan berpengaruh positif dan signifikan terhadap kepatuhan wajib pajak.

\section{E. Simpulan, Keterbatasan dan Kontribusi Praktis}

\section{Simpulan}

a. Sosialisasi perpajakan mempunyai peranan yang sangat penting dalam meningkatkan kepatuhan wajib pajak orang pribadi, oleh karena itu faktor-faktor yang menimbulkan tingginya kepatuhan wajib pajak orang pribadi harus mendapatkan perhatian yang serius.

b. Dengan meningkatkan sanksi perpajakan maka akan memberikan kontribusi yang besar terhadap kepatuhan wajib pajak orang pribadi pada KPP Pratama Surakarta. Oleh karena itu, sanksi perpajakan yang penerapannya dilakukan secara tegas kepada wajib pajak akan mengakibatkan wajib pajak jera untuk lalai dalam melakukan kewajiban perpajakannya.

\section{Keterbatasan}

Penelitian ini hanya fokus pada faktor-faktor yang mempengaruhi kepatuhan wajib pajak, dengan hanya memfokuskan variabel independen sosialisasi perpajakan dan sanksi perpajakan untuk variabel dependen kepatuhan wajib pajak. Sedangkan aspek-aspek lain yang mungkin juga berpengaruh terhadap kepatuhan wajib pajak tidak ikut diteliti. Penelitian ini hanya terbatas pada Kantor Pelayanan Pajak (KPP) PRATAMA Surakarta.

\section{Kontribusi Praktis}

Mempercepat peningkatan sumber penerimaan utama negara yang digunakan untuk membiayai pengeluaran pemerintah dan pembangunan.

\section{F. Daftar Pustaka}

Chau, Liung. 2009. A Critical Review of Fischer Tax Compliance Model. Journal of Accounting and Taxation.

Doran, Michael. 2009. Tax Penaltie and Tax Compliance. Harvard Journal On Legislation. Vol. 46. page:111161.

Gedhe Pani Esa Dharma \& Ketut Alit Suardana. 2014. Pengaruh Kesadaran Wajib Pajak, Sosialisasi Perpajakan, Kualitas Pelayanan Pada Kepatuhan Wajib Pajak. E-Jurnal Akuntansi Universitas Udayana 6.1 (2014): 340-353.

Gerald, Chau and Patrick Leung. 2009. A Critical Review of Fischer Tax Compliance Model (A Research Syntesis). Journal of Accounting and Taxation. 1(2): h:34-40.

Ghozali, Imam. 2001. Aplikasi Analisis Multivariate dengan Program SPSS Edisi 3, Semarang: Universitas Diponegoro Semarang.

G. Wijayanto, 2017. Pengaruh Sosialisasi Perpajakan dan Pemahaman Prosedur Perpajakan Terhadap Kepatuhan Wajib Pajak dalam Memenuhi Kewajiban PBB P2 di Kota Magelang. Jurnal Profita Edisi 1 Tahun 2017. 
I Made Wahyu Cahyadi, 2016. Pengaruh Kesadaran, Sosialisasi, Akuntabilitas Pelayanan Publik dan Sanksi Perpajakan Pada Kepatuhan Wajib Pajak Kendaraan Bermotor. E-Jurnal Akuntansi Universitas Udayana, $16,2342-2373$.

Ida Ayu Dewi Widnyani, 2016. Pengaruh Sosialisasi, Sanksi dan Persepsi Akuntabilitas Terhadap Kepatuhan Waib Pajak Dalam Membayar Pajak Kendaraan Bermotor. E-Jurnal Akuntansi Universitas Udayana, 16, 2176-2203.

Jatmiko, Agus Nugroho. 2006. Pengaruh Sikap Wajib Pajak pada Pelaksanaan Denda, Pelayanan Fiskus, dan Kesadaran Perpajakan Terhadap Kepatuhan Wajib Pajak. eprints.undip.ac.id/ 15261/1/Agus_Nugroho_Jatmiko.pdf.

Mardiasmo, 2016. Perpajakan edisi revisi 2009. Yogyakarta, Andi.

Mohammad Zain, 2007. Manajemen Perpajakan. Jakarta: Penerbit SalembaEmpat.

Nazmel, Nazir. 2010. Pengaruh Pengetahuan Pajak dan Sistem Administrasi Perpajakan Terhadap Kepatuhan Wajib Pajak (Survei atas WP-OP PBB di KPP Pratama Jakarta Pasar Rebo). Jurnal Informasi, Perbankan, dan Keuangan Publik.Vol. 5.No. 2.Juli 2010.

Ocheni, Stephen. 2015. A Causality Analysis between Tax Compliance Behaviour and Nigerian Economic Growth. Mediterranean Journal of Social Sciences MCSER Publishing, Rome-Italy. 6(1): pp:2039-2117.

R. Viktor Billi Josua Tawas, Agus T. Poputra, 2016. Pengaruh Sosialisasi Perpajakan, Tarif Pajak, dan Sanksi Perpajakan Terhadap Kepatuhan Pelaporan SPT Tahunan Wajib Pajak Orang Pribadi (Studi Kasus Pada KPP Pratama Bitung). Jurnal EMBA, 4(4), 912-921.

Sugeng, Wahono, 2012, Teori dan Aplikasi: Mengurus Pajak itu Mudah. Mojokerto: Gramedia Direct.

Sugiyono. 2010. Statistika untuk Penelitian. Bandung: Alfabeta.

Susilawati, Ketut Evi dan Ketut Budiartha. 2013. Pengaruh Kesadaran Wajib Pajak, Pengetahuan Pajak, Sanksi Perpajakan dan Akuntabilitas Pelayanan Publik Pada Kepatuhan Wajib Pajak Kendaraan Bermotor. EJurnal Akuntansi Universitas Udayana 4.2 h:345-357. ISSN: 2303-8556.

Torgler, B. 2005. Direct Democracy and Tax Morale. European Journal of Political Economy. 21, h:525-531.

Widayat, 2004 : "Metode Penelitian Pemasaran", Malang, UMM Press

Winerungan, Oktaviane Lidya, 2013. "Sosialisasi Perpajakan, Pelayanan Fiskus dan Sanksi Perpajakan Terhadap Kepatuhan WPOP di KPP Manado dan KPP Bitung”. Jurnal Emba, Vol. 1, No. 3, Hal: 960 970.

Witte, A. D dan D. F Woodbury. 1985. The Effect of Tax Laws and Tax Administration on Tax Compliance: The Case of the U.S Individual Income Tax. National Tax Journal. 38(1): pp:1-13. 